\title{
EMPIRICAL DRYING MODEL FOR THE MASS TRANSFER AND DRYING KINETICS OF TREATED AND UNTREATED SABA BANANA SLICES
}

\author{
ALAGBE E. E.*1, DANIEL E. O. ${ }^{2}$, AMLABU Y. $\mathrm{S}^{1}$ \& SOLE-ADEOYE $0 .^{3}$ \\ ${ }^{1}$ Department of Chemical Engineering, Covenant University, Ota. Nigeria \\ ${ }^{2}$ Department of Microbiology, Benson Idahosa University, Benin City, Nigeria.
}

${ }^{3}$ Department of Production, Analytical and laboratory Management, Federal Institute of Industrial Research, Oshodi. Nigeria

\section{ABSTRACT}

Banana fruit is a delight in most Nigerian homes, which is usually eaten fresh, but recently, dried bananas have found their way into the daily snacks. Unfortunately, this precious fruit suffers a huge post-harvest loss due to its high moisture content. This work includes the fitting of the drying process to empirical models to predict the drying process using a locally fabricated convective tray dryer. To prevent discolouring during drying, samples were treated with a 1:4 lemon juice. Drying was carried out (for both treated and untreated samples) at temperatures of $40{ }^{\circ} \mathrm{C}, 50{ }^{\circ} \mathrm{C}, 60{ }^{\circ} \mathrm{C}$, and $70^{\circ} \mathrm{C}$. Four empirical models were examined (Newton, Peleg, Henderson-Pabis, and Logarithmic models), and the model with the highest $\boldsymbol{R}^{2}$ and least RMSE values was adopted as the best fit for each drying temperature. Results showed that the Peleg model favoured air-drying and at temperatures of $50^{\circ} \mathrm{C}$ and $60^{\circ} \mathrm{C}$ for untreated and treated samples, respectively, while other models considered, best described the drying at other temperatures, for both treated and untreated samples.

KEYWORDS: Post-Gather, Nourishment, Empirical Models, Drying of Fruits, Mass Transfer

Received: Jul 27, 2020; Accepted: Jul 17, 2020; Published: Nov 09, 2020; Paper Id.: IJMPERDOCT202035

\section{INTRODUCTION}

Banana is an organic product yield of substantial monetary and wholesome importance that is cultivated in tropical and subtropical areas. In developing nations, the reported consumption of bananas is about $21 \mathrm{~kg}$ for each individual every year [1]. Banana contains a reasonable amount of starches, minerals, protein, sugar, and vitamin A [2]. Be that as it may, the organic product is truly susceptible to biological degradation due to its high water content in the fresh fruit. This, in turn, attracts great misfortunes with a lack of strategies for collecting and postgather $[3,4,5,6]$. Drying is an old technique for safeguarding nourishment, and this includes the evacuation of the more significant part of the water typically present in the sustenance by dissipation [7, 8]. Drying is a standout amongst the most broadly utilized procedures for safeguarding nourishments, as it diminishes microbial development and deteriorative compound responses. In any case, an ill-advised drying procedure can prompt undesirable changes in concoction creation and structure of the organic product tissues, bringing about terrible utilization quality as far as shading, surface, and healthful qualities [9]. This behooves a banana drying process must be controlled painstakingly to attain the desired quality traits in the dried products [10]. This would allow for modification of drying parameters, within reasonable limits, to guarantee excellent quality dried products. Dried bananas and its peels have various uses in baby and adult food/snacks and the production of activated carbon [11], respectively. 
The tray dryer is used mostly in industries because of its simple design and capability to dry products at high volume (12), which guarantees hygiene during the process (13) Generally, a tray dryer is fed with fan-distributed hot air to its stack of trays. Tray dryers can be operated batch-wise, as racks to hold products while air circulates over the material (14). The raw food samples are spread out on the trays at an acceptable thickness so that the product can be dried uniformly $[12,15]$.

Modeling of drying processes and kinetics helps in the analysis of the transfer process and equipment design [16]. These mathematical models give useful insight into the drying process and estimate the drying time of different agricultural products [17]. Therefore, the choice of the most appropriate method of drying for a particular product is essential and these models could be theoretical, semi-theoretical, or empirical models [18]. Semi-theoretical drying models are founded on the diffusion theory, which assumes a resistance to moisture in a product that occurs in the product layer [19]. Thus, from Newton's law of cooling, the drying rate can be expressed as;

$$
\begin{aligned}
& \frac{\partial M}{\partial t}=-k\left(M-M_{e}\right) \\
& \text { where, } \\
& \text { k- drying coefficient; } \\
& M_{e} \text { - equilibrium moisture content } \\
& \text { M- average moisture content product }
\end{aligned}
$$

Kinetics of drying describes the changes in the amount of moisture present in a material during the process [20]. It can be impacted by drying temperature/time, drying temperature, relative air humidity, flow rate (or velocity) of the drying air, material thickness/diameter, $[21,22]$. The composition of the food products can also affect the drying kinetics of that particular product [20].

With different species of banana currently in the Nigerian market, it is imperative to know the drying models that best describe their drying. Therefore, this work serves to present the drying kinetics and also, the models that best describe the drying properties of the relatively common Saba banana specie.

\section{METHODOLOGY}

The ripe saba bananas used for this experiment were bought from Cafeteria 1 in Covenant University, Ota, Nigeria. The Eureka lemon (citrus limon 'Eureka') used to pre-treat the banana slices were purchased from Shoprite, Circle mall, Jakande, Lagos.

\subsection{Preparation and Pre-Treatment of Banana Slices}

The bananas were peeled and sliced equally using a banana slicer to a thickness of about $5 \mathrm{~mm}$. $100 \mathrm{~g}$ of sliced samples were weighed with the measuring scale and dipped in a 1:4 lemon and water solution for 10 minutes. After 10 minutes, the banana slices were drained correctly and spread out on a foil paper. $100 \mathrm{~g}$ of banana slices were weighed with a measuring scale and spread evenly on a foil paper.

\subsection{Drying of Banana Slices}

The tray drying process was carried out using a tray dryer consisting of two trays. The banana slices were dried at four 
different temperatures $\left(40^{\circ} \mathrm{C}, 50^{\circ} \mathrm{C}, 60^{\circ} \mathrm{C}\right.$ and $\left.70^{\circ} \mathrm{C}\right)$ with a steady air velocity of $1.2 \mathrm{~m} / \mathrm{s}$ and relative humidity of 65 . To ensure uniformity in drying, both the untreated and treated banana slices were dried simultaneously but loaded on separate trays. The weights of the banana samples were monitored and taken at an interval of thirty minutes until a constant weight was reached. Each weighing was repeated three times.

Control samples were treated and untreated sun-dried banana slices. The samples were weighed regularly at an interval of sixty (60) minutes until a constant weight was obtained.

\subsection{Derivation of Thin-layer Drying Models}

Existing derived models were used to predict and describe the drying process. Table 1 shows the mathematical models that were employed.

Table 1: Mathematical models for the description of drying kinetics of agricultural products [21]

\begin{tabular}{|l|l|l|}
\hline \multicolumn{1}{|c|}{ SN } & \multicolumn{1}{|c|}{ MODEL NAME } & \multicolumn{1}{|c|}{ MODEL EQUATION } \\
\hline 1 & Newton/ Lewis & MR $=\exp (-\mathrm{kt})$ \\
\hline 2 & Peleg Model & $M-M_{0}=\frac{1}{k_{1}+t k_{2}}, \frac{d M}{d t}=M R=\frac{-k_{1}}{k_{1}+t k_{2}}$ \\
\hline 3 & Henderson and Pabis & $\mathrm{MR}=\mathrm{aexp}(-\mathrm{kt})$ \\
\hline 4 & Logarithmic & $\mathrm{MR}=\mathrm{a} \exp (-\mathrm{kt})+\mathrm{c}$ \\
\hline
\end{tabular}

Where,

MR- moisture ratio

t- time of drying

k- drying coefficient

a, b, n, c, g are model constants

\section{RESULTS AND DISCUSSIONS}

Table 2: Effect of drying temperature on moisture variation of untreated samples during drying

\begin{tabular}{|c|c|c|c|c|c|}
\hline \multicolumn{6}{|c|}{ UNTREATED } \\
\hline TEMPERATURE & $40^{\circ} \mathrm{C}$ & $50^{\circ} \mathrm{C}$ & $60^{\circ} \mathrm{C}$ & $7^{\circ} \mathrm{C}$ & AIR-DRIED \\
\hline TIME & \%MOISTURE & \%MOISTURE & \%MOISTURE & \%MOISTURE & \%MOISTURE \\
\hline 0 & 0.666 & 0.666 & 0.666 & 0.666 & 0.666 \\
\hline 30 & 0.628 & 0.602 & 0.591 & 0.588 & \\
\hline 60 & 0.598 & 0.565 & 0.519 & 0.524 & 0.644 \\
\hline 90 & 0.576 & 0.508 & 0.460 & 0.449 & \\
\hline 120 & 0.551 & 0.481 & 0.384 & 0.293 & 0.592 \\
\hline 150 & 0.527 & 0.425 & 0.317 & 0.256 & \\
\hline 180 & 0.496 & 0.387 & 0.271 & 0.215 & 0.554 \\
\hline 210 & 0.478 & 0.332 & 0.190 & 0.200 & \\
\hline 240 & 0.395 & 0.295 & 0.159 & 0.169 & 0.513 \\
\hline
\end{tabular}




\begin{tabular}{|c|c|c|c|c|c|}
\hline 270 & 0.361 & 0.205 & 0.108 & 0.169 & \\
\hline 300 & 0.332 & 0.187 & 0.108 & 0.169 & 0.483 \\
\hline 330 & 0.302 & 0.150 & 0.108 & & \\
\hline 360 & 0.312 & 0.131 & 0.108 & & 0.449 \\
\hline 390 & 0.279 & 0.131 & & & \\
\hline 420 & 0.279 & 0.131 & & & 0.403 \\
\hline 450 & 0.256 & 0.131 & & & \\
\hline 480 & 0.256 & 0.131 & & & 0.367 \\
\hline 510 & 0.256 & & & & \\
\hline 540 & 0.231 & & & & 0.338 \\
\hline 570 & 0.231 & & & & \\
\hline 600 & 0.231 & & & & 0.305 \\
\hline 630 & 0.231 & & & & \\
\hline 660 & 0.231 & & & & 0.269 \\
\hline 690 & & & & & \\
\hline 720 & & & & & 0.256 \\
\hline 750 & & & & & \\
\hline 780 & & & & & 0.215 \\
\hline 810 & & & & & \\
\hline 840 & & & & & 0.169 \\
\hline 870 & & & & & \\
\hline 900 & & & & & 0.169 \\
\hline 930 & & & & & \\
\hline 960 & & & & & 0.169 \\
\hline
\end{tabular}

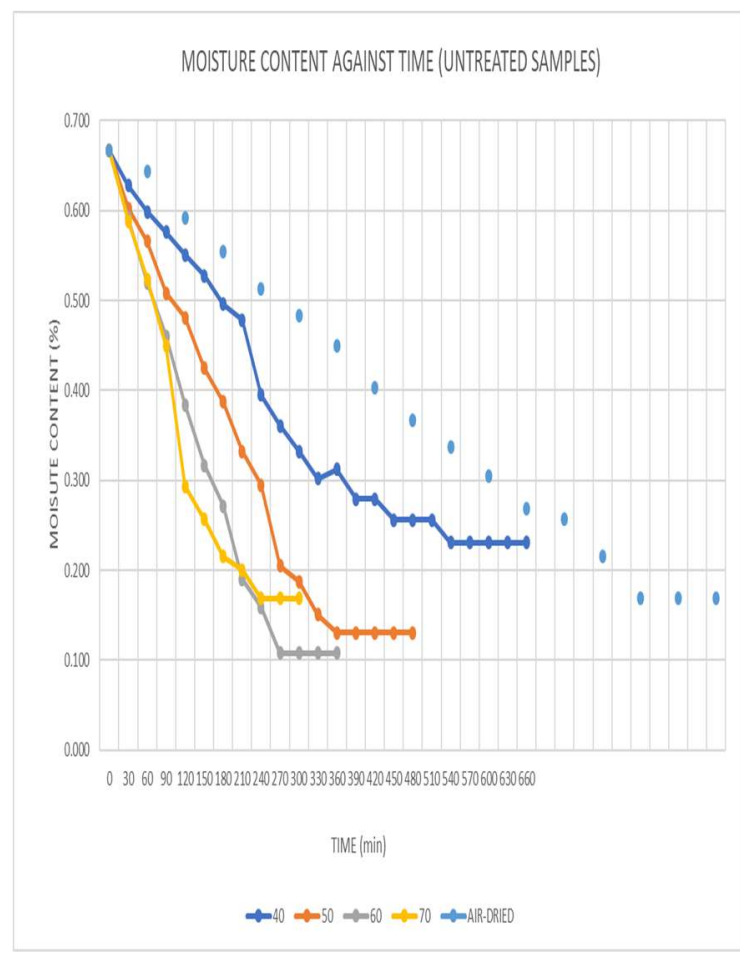

Figure 1: Plot of variation of moisture content versus time at different temperatures of treated banana slices 
Figure 1 shows that for the untreated samples, drying took place mainly in the falling rate region, for all temperatures.

Table 2 shows the effect of time and temperature on the moisture content present in the untreated banana slices when dried. The initial moisture content of the untreated banana slices was $66.6 \%$. The final moisture content of the untreated banana samples was $23.1 \%, 13.1 \%, 10.8 \%, 16.9 \%$ and $16.9 \%$ at $40{ }^{\circ} \mathrm{C}, 50{ }^{\circ} \mathrm{C}, 60{ }^{\circ} \mathrm{C}, 70{ }^{\circ} \mathrm{C}$ and air-drying temperature. The moisture content present in the banana samples were decreasing with an increase in temperature except at $70^{\circ} \mathrm{C}$. This is because, at a high temperature of $70{ }^{\circ} \mathrm{C}$, a dried layer was formed on the surface of the banana slices, which made drying difficult. Hence, its higher final moisture content.

Table 3: Effect of drying temperature on moisture variation of treated samples during drying

\begin{tabular}{|c|c|c|c|c|c|}
\hline \multicolumn{6}{|c|}{ Treated } \\
\hline & 40 & 50 & 60 & 70 & AIR-DRIED \\
\hline Time & $\begin{array}{c}\% \\
\text { Moisture }\end{array}$ & $\begin{array}{c}\% \\
\text { Moisture }\end{array}$ & $\%$ Moisture & \% Moisture & $\begin{array}{c}\% \\
\text { Moisture }\end{array}$ \\
\hline 0 & 0.699 & 0.699 & 0.699 & 0.699 & 0.699 \\
\hline 30 & 0.663 & 0.640 & 0.608 & 0.609 & \\
\hline 60 & 0.630 & 0.582 & 0.551 & 0.538 & 0.671 \\
\hline 90 & 0.597 & 0.536 & 0.467 & 0.459 & \\
\hline 120 & 0.572 & 0.487 & 0.420 & 0.335 & 0.631 \\
\hline 150 & 0.534 & 0.434 & 0.344 & 0.285 & \\
\hline 180 & 0.523 & 0.389 & 0.273 & 0.227 & 0.600 \\
\hline 210 & 0.488 & 0.348 & 0.167 & 0.211 & \\
\hline 240 & 0.390 & 0.287 & 0.131 & 0.194 & 0.549 \\
\hline 270 & 0.362 & 0.215 & 0.111 & 0.194 & \\
\hline 300 & 0.320 & 0.181 & 0.111 & 0.194 & 0.515 \\
\hline 330 & 0.308 & 0.163 & 0.111 & & \\
\hline 360 & 0.272 & 0.163 & 0.111 & & 0.476 \\
\hline 390 & 0.272 & 0.145 & & & \\
\hline 420 & 0.272 & 0.125 & & & 0.438 \\
\hline 450 & 0.272 & 0.125 & & & \\
\hline 480 & 0.259 & 0.125 & & & 0.374 \\
\hline 510 & 0.246 & & & & \\
\hline 540 & 0.217 & & & & 0.295 \\
\hline 570 & 0.217 & & & & \\
\hline 600 & 0.217 & & & & 0.282 \\
\hline 630 & 0.217 & & & & \\
\hline 660 & 0.217 & & & & 0.239 \\
\hline 690 & & & & & \\
\hline 720 & & & & & 0.192 \\
\hline 750 & & & & & \\
\hline 780 & & & & & 0.192 \\
\hline 810 & & & & & \\
\hline 840 & & & & & 0.157 \\
\hline 870 & & & & & \\
\hline
\end{tabular}




\begin{tabular}{|c|l|l|l|l|l|}
\hline 900 & & & & & 0.118 \\
\hline 930 & & & & & \\
\hline 960 & & & & & 0.118 \\
\hline
\end{tabular}

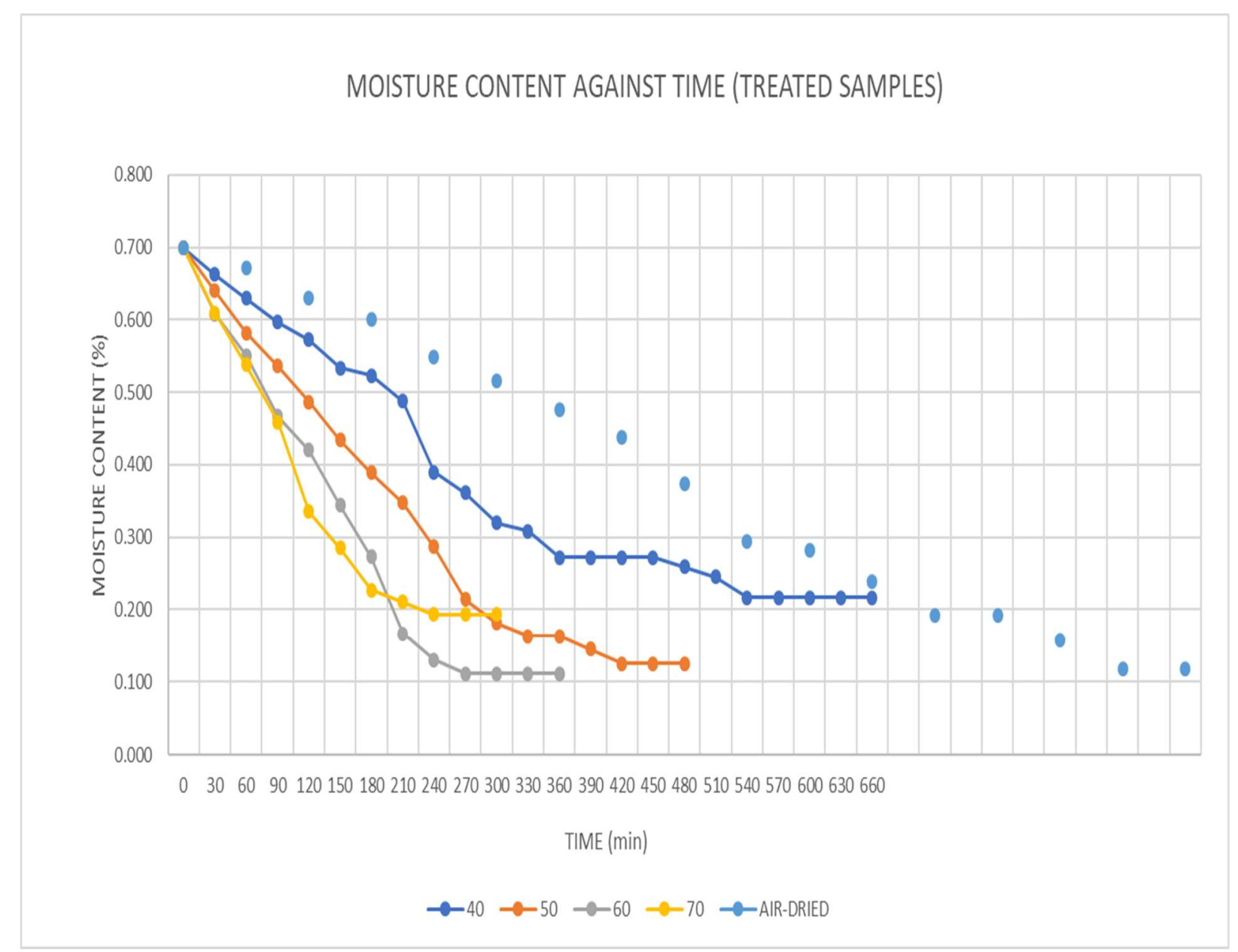

Figure 2: Plot of variation of moisture content of treated banana slices versus time at different temperatures

Figure 2 shows that for the treated samples, drying occurred mainly in the falling rate region, also, for all temperatures under investigation.

Table 3 portrays the effect of time and temperature on the moisture content present in the treated banana slices. The initial moisture content of the untreated banana slices was $66.6 \%$. The final moisture content of the untreated banana samples was $21.7 \%, 12.5 \%, 11.1 \%, 19.4 \%$ and $11.8 \%$ at $40^{\circ} \mathrm{C}, 50^{\circ} \mathrm{C}, 60^{\circ} \mathrm{C}, 70^{\circ} \mathrm{C}$ and air-drying temperature. The moisture content present in the banana samples was decreasing with an increase in temperature except for $70^{\circ} \mathrm{C}$. This is because, at a high temperature of $70^{\circ} \mathrm{C}$, a dried crust is formed in the surface of the banana slices, which makes drying difficult hence, a higher moisture content. This is similar to the results obtained in the treated samples.

\subsection{Drying Models}

Drying data obtained were fitted into four empirical drying models to describe the drying kinetics of banana. The drying models with the highest value of $\mathrm{R}^{2}$ and the lowest value of RMSE were taken as the model(s) that best described the drying of banana samples. Below are a few of the selected models; 
Table 4: Results of $\mathbf{R}^{2}$ and Root Mean Square Error (RMSE) obtained at different temperatures with varying theoretical models for untreated banana samples

\begin{tabular}{|l|l|l|l|l|}
\hline \multicolumn{1}{|c|}{$\begin{array}{c}\text { Models/Temperature, } \\
{ }^{\mathbf{C}} \mathbf{C}\end{array}$} & $\begin{array}{c}\text { Newton } \\
\mathbf{R}^{2} \text { value } \\
\text { (deviation) }\end{array}$ & $\begin{array}{c}\text { Peleg } \\
\mathbf{R}^{2} \text { value } \\
\text { (deviation) }\end{array}$ & $\begin{array}{c}\text { Henderson and } \\
\text { Pabis } \\
\mathbf{R}^{2} \text { value } \\
\text { (deviation) }\end{array}$ & \multicolumn{1}{|c|}{$\begin{array}{c}\text { Logarithmic } \\
\mathbf{R}^{\mathbf{2}} \text { value } \\
(\mathbf{d e v i a t i o n})\end{array}$} \\
\hline 40 & $0.9713(0.06)$ & $0.9503(0.05)$ & $0.9721(0.05)$ & $0.9713(0.06)$ \\
\hline 50 & $0.9609(0.09)$ & $0.9932(0.04)$ & $0.9609(0.09)$ & $0.9609(0.09)$ \\
\hline 60 & $0.9959(0.00)$ & $0.994(0.03)$ & $0.9959(0.03)$ & $0.9959(0.00)$ \\
\hline 70 & $0.9739(0.09)$ & $0.9445(0.06)$ & $0.9739(0.09)$ & $0.9739(0.09)$ \\
\hline Air-dried & $0.9743(0.03)$ & $0.9965(0.02)$ & $0.9743(0.03)$ & $0.9743(0.03)$ \\
\hline
\end{tabular}

Table 4 shows that both air-dried samples and samples dried at $50{ }^{\circ} \mathrm{C}$ followed the Peleg model while at other temperatures, the Peleg model was not favoured. Drying at $60{ }^{\circ} \mathrm{C}$ and $70{ }^{\circ} \mathrm{C}$ followed all models except Peleg, while at 40 ${ }^{0} \mathrm{C}$, the combined Henderson-Pabis model best described its drying kinetics. Considering same convective drying on banana slices and peels, the thin-layer drying in the works of Da Silva et al. (2013) [23] and Khawas et al. (2014) [24] respectively, followed the Page models while microwave drying of banana slices followed Wang and Singh model [20].

Table 5: Results of $\mathbf{R}^{2}$ and Root mean square Error (RMSE) obtained at different temperatures with varying theoretical models for treated banana samples

\begin{tabular}{|c|c|c|c|c|}
\hline $\begin{array}{c}\text { Models/Temperature, } \\
{ }^{\mathbf{0}} \mathbf{C}\end{array}$ & $\begin{array}{c}\text { Newton } \\
\mathbf{R}^{\mathbf{2}} \text { value } \\
\text { (deviation) }\end{array}$ & $\begin{array}{c}\text { Peleg } \\
\mathbf{R}^{\mathbf{2}} \text { value } \\
\text { (deviation) }\end{array}$ & $\begin{array}{c}\text { Henderson and } \\
\text { Pabis } \\
\mathbf{R}^{2} \text { value } \\
\text { (deviation) }\end{array}$ & $\begin{array}{c}\text { Logarithmic } \\
\mathbf{R}^{\mathbf{2}} \text { value } \\
\text { (deviation) }\end{array}$ \\
\hline 40 & $0.9627(0.06)$ & $0.9396(0.05)$ & $0.9627(0.06)$ & $0.9627(0.06)$ \\
\hline 50 & $0.9804(0.06)$ & $0.9689(0.04)$ & $0.9804(0.06)$ & $0.9804(0.06)$ \\
\hline 60 & $0.9547(0.10)$ & $0.9899(0.05)$ & $0.9547(0.12)$ & $0.9547(0.10)$ \\
\hline 70 & $0.9812(0.08)$ & $0.9541(0.06)$ & $0.9812(0.08)$ & $0.9812(0.08)$ \\
\hline Air-dried & $0.9628(0.06)$ & $0.9903(0.02)$ & $0.9628(0.06)$ & $0.9628(0.06)$ \\
\hline
\end{tabular}

Table 5 shows that the Peleg model best describes the drying kinetics of the air-dried samples and samples dried at $60^{\circ} \mathrm{C}$. at other temperatures, the Peleg model failed to qualify as best representing the drying kinetics while other models had equivalent statistical indicators.

The Henderson-Pabis model woefully represented the drying of banana specie (Musa acuminata) in Brazil while the Peleg model weakly represented the drying kinetics [23]. Works of Dandarongrak et al. (2002) [25], where treated banana slices were dried using a heat pump dehumidifier, followed the two-term exponential model.

\section{CONCLUSIONS}

The models that describe the drying kinetics of banana may be a function of the location of cultivation, that is, the prevailing climatic conditions, and the type of dryer used in the drying process. The Peleg model may be adopted for drying at $50{ }^{\circ} \mathrm{C}, 60^{\circ} \mathrm{C}$, and air-dried samples. In contrast, other models with similar statistical indicators may be used to describe the drying kinetics at other temperatures under investigation.

\section{ACKNOWLEDGEMENT}


The Team would like to appreciate the Management of Covenant University, Ota, for her financial support in the publication of this manuscript and also, Benson Idahosa University, Benin City, and the Federal Institute of Industrial Research, Oshodi (FIIRO) for collaborative support.

\section{CONFLICT OF INTEREST}

None declared by the members of the Team.

\section{REFERENCES}

1. Toledo T. T., Nogueria S. B., Cordenunsi B. R., Gozzo F. C., Pilau E. J., Lajoj F. M, Nascimento J. R. (2012) 'Proteomic Analysis of Banana Fruit Reveals Proteins That are Differentially Accumulated During Ripening. '” Postharvest Biology and Technology, Vol. no. 70, pp. 51-58.

2. Silva W. P, Silva C. M, Gama F. J., Gomes J. P. (2013) 'Mathematical Models to Describe Thin-Layer Drying and to Determine Drying rate of Whole Bananas.' Journal of the Saudi Society of Agricultural Sciences, Vol. 13, pp. 67-74.

3. Ricardo L. M, Brun A. M, Joao B. L. (2016) 'A microwave multi-flash drying process for producing crispy bananas. ' Journal of Food Engineering, pp. 1-11.

4. . Pan Z, et al. (2008) 'Study of banana dehydration using sequential infrared radiation heating and freeze-drying." LWTFood Science and Technology, pp. 1944-1951.

5. Hassan MK et al. (2004) 'Extension of banana shell life." Australas Plant Pathol, p. 305.

6. Kibangu-Nkembo T. S. (2004) 'Comparative study of natural solar drying of cassava, banana, and mango."' Renew Energy, pp. $975-990$.

7. Tripathy S., Raj J. D., Mishra M. (2016) 'Study on Drying and Quality Characteristics of Tray and Microwave Dried Guava. " International Journal of Scientific and Engineering Research, Vol. 7, pp. 965-970.

8. Alagbe E. E., Daniel E. O., Oyeniy E. A. (2020) 'Dataset on the effect of pre-treatment on the proximate analysis, microbial and sensory evaluation of dried banana during storage. Data in Brief. Vol. 31.

9. Nguyen-Do-Trong N., Dusabumuremyi J. C., Saeys W. (2018) 'Cross-Polarized VNIR Hyperspectral Reflectance Imaging for Non-Destructive Quality Evaluation of Dried Banana Slices, Drying Process Monitoring, and Control.' Journal of Food Engineering, Vol. 238, pp. 85-94.

10. Aghbalso M., Hossenpour S., Ghasemi-Varnamkhasti M. (2014) 'Computer vision for real-time food quality assurance during the drying process."' Trends Food Science Technology, Vol. 39, pp. 76-84.

11. Efeovbokhan V. E., Alagbe E. E., Odika B., Abatan O. G., Yusuf E. O.. (2019) 'Preparation and characterization of activated carbon from plantain peel and coconut shell using biological activators.' Journal of Physics: Conference.

12. Suhaim M., Mat S., Ruslan M. H., K. Sopian, Salleh E. (2013) 'The prediction of drying uniformity in the tray system using CFD simulation." International Journal of Matching Learning and Computing, pp. 419-423.

13. Doymaz I. (2010) 'Evaluation of mathematical models for prediction of thin-layer drying of banana slices." International Journal of Food Properties, Vol. 13, pp. 486-497.

14. Goud V. V., Golder A. K. (2014)Chemical Engineering Design II. Retrieved from https://nptel.ac.in: https://nptel.ac.in/downloads/103103027/. [Online], 2014.

15. Alagbe E. E., Amlabu Y. S., Daniel E. O., Ojewumi M. E.. (2020) 'Effect of varying temperatures on the soluble sugar and 
nutritional content of banana."' Open Chemical Engineering Journal.. Vol. 14, pg 11-16.

16. Menges H. O., Ertekin C. (2006) "Mathematical modeling of thin-layer drying of golden apples." Journal of Food Engineering, pp. 119-125.

17. Ayoola P. O., Goodluck E. O. (2015) 'Modeling drying characteristics of moringa (Moringa Oleifera) leaves under a mechanical convective dryer." Annals. Food Science and Technology, p. 36.

18. Seiledlou S., Ghasemzadeh H. Hamdami R., N., . Talati M. M. (2010) 'Convective Drying of Apple: Mathematical Modeling and Determination of Some Quality Parameter.' International Journal of Agriculture and Biology, pp. 171-178.

19. Ertekin C., Fira Z. A. (2015) 'Comprehensive Review of Thin Layer Drying Models Used in Agricultural Products.'” Critical Reviews in Food Science and Nutrition, pp. 1-71.

20. Adewale O. O., Afam I. O., Patrick F. K. (2014) 'Modeling microwave drying kinetics and moisture diffusivity on Mabonde banana variety. ' International Journal of Agricultural and Biological Engineering, Vol. 7, pp. 107-113.

21. Inyang U. E., Oboh I. O., Etuk B. R. (2018) 'Kinetic Models for Drying Techniques-Food Materials." Advances in Chemical Engineering and Science, pp. 27-48.

22. Chayjan R. A. (2012) 'Modeling Some Drying Characteristics of High Moisture Potato Slices in Fixed, Semi Fluidized, and Fluidized Bed Conditions. ' Journal of Agricultural Science and Technology, pp. 1229-1241.

23. Pereira da Silva W. et al. (2014) 'Mathematical models to describe thin-layer drying and to determine the drying rate of whole bananas. ' Journal of Saudi Society of Agricultural Sciences, pp. 67-74.

24. Khawas P. D. A., Dash K. K., Deka S. C. (2014) 'Thin-layer drying characteristics of Kachkal banana peel (Musa ABB) of Assam, India." International Food Research Journal, Vol. 21, pp. 1011-1018.

25. Dandamrongrak R., Young G., Mason R. (2002) 'Evaluation of various pre-treatments for the dehydration of banana, a selection of suitable drying models. "'Journal of Food Engineering, Vol. 55, pp. 139-146, Feb, 2002. 

